DOI: 10.20472/BMC.2017.006.001

\title{
KHATUNA BERISHVILI
}

Tbilisi State University, Georgia

\section{CONTRADICTORY CHARACTER OF THE PROCESS OF LIBERALIZATION AND INTEGRATION OF ECONOMIC RELATIONS AND INFLUENCE OF THIS PROCESS ON THE COUNTRIES WITH SMALL ECONOMY}

\begin{abstract}
:
Integration into the international economic processes and liberalization of foreign economic ties are a prerequisite for the economic development of those developing countries, which have small economy. Present level of globalization highlighted the issues of liberalization of economic activity, but by the scientists' opinion the economic results of this process are ambiguous. Peculiarities and influence of liberalization on the national economy are of a controvercial character when interests of the general public are suffered in this process. The issue of integration into the world economy passes from economic to socio-political plane. The present thesis is clearly seen today in the activities of many states, among them, in the activities of Georgia, which at the world markets in conditions of crisis and turbulence is searching for the mechanisms of protection of national producers and grows the scales of protectionism. It is also logical that determination of optimal integrational processes and their use in small economies of developing countries remain urgent in conditions of the present-day turbulence.
\end{abstract}

\section{Keywords:}

integration, liberalization, foreign trade, optimization, small economy, development.

JEL Classification: M16 


\section{Introduction}

Contemporary economic studies mostly discuss positive influence of economic integration and liberalization of foteign trade on economic development of the countries with small economy. Liberalization of markets is focused on stimulation of economic growth and development and positive reflection on wellbeing of the consumers. Contemporary level of globalization made liberalization of economic activity most important, but economic results of this process sre not uniform from the viewpoint of both national economies and, on the whole, the entire world. In conditions of the present-day economic turbulence an optimal use of the integrational processes in small economies of the transitional countries is a most complicated and important task.

\section{Review of the Problem}

To determine relevance of the problem it is necessary to give general theoretical evaluation to the global integrational processes and to assess their influence on liberalization of the foreign economic activity. By today, in conditions of full or partial liberalization, many studies exist concerning the issue of the world economy modelling. More often, a basic starting point is selected to be realization of main ideas of Doha round in the WTO (World Trade Organization) talks, which were oriented to the principle of openness of economies [Lynn, 2012]. Main purpose of the non-statistical methods (mostly of expert evaluations) of use of mathematical models of different scenarios is to establish the scales of influence of the world economy liberalization on the countries and separate regions. Despite essential methodological difference of these models, a general approach to the change of world economy presented in them is unified, which witnesses unity of scientific approaches to liberalization, as to the most attractive and undoubtedly required variant [Bount, 2016].

Majority of the scientific studies witness a positive contribution of liberalization on the world economy growth. By the data of A. Bount, full liberalization, abolishment of tariffs, internal subsidies and donations will cause growth of the world wellbeing (of general income) by USD 100 billion, i.e. 0, 33\% of the world GDP. At the same time, 73, 8\% of the world income comes on developed countries, $24,1 \%$ - on developing countries and $2,2 \%$ - on the category of the least developing countries [Bount, 2016]. By the evaluation of Pascal Lamm, general positive effect will equal USD 130 billion [OECED, 2015]. More optimistic studies also exist, which cite the data of high reliability with entirely other proportions of divisions of final results among the countries. Finally, the scientists come to the conclusion that general effect of liberalization can, possibly, be inessential for the world, but positive, though conditional 
assumptions always exist. We should understand that liberalization does not bring benefit to absolutely all members of the society. In result of liberalization, individual entrepreneurs, in the process of redistribution of production functions and new flows of profit, can experience losses. This principle is acknowledged in the fundamental studies on international business, which on the whole support policy of liberalization. At the same time, it is also clear that when the nations receive profit from the international trade (in conditions of liberalization), it is also possible that the international trade can damage separate groups inside the nations [Charnovitz, 2016].

In the study of famous scientist R. Driskill it is sunstantiated that even in the widely used basic models of the foreign trade, which attach a priority to free trade (D. Ricardo, HeksherOlin), essential contradictions exist (R. Driskill, 2015). The issues on distribution of potential effects depend on specialization of the country and its competitive advantages, but distribution of profit inside the nation, first of all, is determined by distribution of the rights of ownership on the production factors. Profit of one group of countries is reached only at the expense of other losses. Potentials for partial compensation of losses to the defeated by the winners, which according to Pareto are necessary for preservation of optimum, are not realizable in real life. Respectively, an actual growth of generral wellbeing cannot be considered positive when the interests of the general public are violated, which in its turn leads to the growth of social tension, instability in the society that in fact is not taken into consideration in the studies of free trade results [Haniotis, 2014].

On the whole, influence of liberalization on the growth of national economy, and in result of this, on reduction of poverty in the country is doubted in the work of P. Rodrigues and D. Rodric (Rodrigues, Rodric, 2015). In this work the authors discuss the peculirities of economic growth in the countries, having high and low trade barriers. Relying on extensive empiric data, the scientists reveal some general tendencies. The thesis of unchanged stimulation of the economic growth in result of free trade is not shared by the scientists. Supporting the liberalization, as a perspective direction, the authors point to existence of various terms, which may make protectionist approaches to be efficient [Dadush, 2012].

In result of the above-mentioned analysis, we come to the conclusion on the need of a balanced approach to the issue of ambivalent assessments of influence of trade liberalization on the national economy and liberalization of the national economy. 


\section{Optimization of Integrational Processes in Small Economies of Transitional Countries}

Georgia's membership in WTO is, surely, a serious step on the way of liberalization of foreign economic activity in the country, but it would not be right to assert that the national economies, in conditions of WTO, act in the regime free from protectionism and the trade is entirely open. Today to support the national economies all the WTO-member countries use a wide range of both tariff and non-tariff restrictions. Even more, if we look, on the whole, at the present-day economic situation and the world trade tendencies, we can notice the tendency of growth in protection measures. Within this context we consider it necessary to study experience of work in the WTO-member countries for its further adaptation and elaboration of efficient foreign trade policy for Georgia in new economic conditions.

In terms of economic crisis, an example of protectionist measures is the so-called American Act of Restoration and Reinvestment, which was adopted in the beginning of 2009 by the US Congress. In compliamce with the present Act, it is forbidden to use the means allocated for reanimation of economy, in construction and repair projects, metallurgy and other spheres, if the resources involved in the project are not produced in the USA [Charnovitz, 2016].

Protectionism appears in a number of small economies of developing countries. Particular difficulties are experienced by the states, which much depend on the US dollar and international markets. For example, Ecuador in July 2009 received WTO official permit on increase of tariffs and quotas. In 2009 Ecuador announced some new import restrictions on 630 commodity positions. This concerned about $8 \%$ of the customs tariff space of the country and $23 \%$ of import. Customs duties increased on more than 350 goods and quota restrictions were introduced on 270 different goods for a year [Driskill, 2015].

In the period of 2008 economic crisis, a new wave of tension appeared between two leading gamblers of the international trade - the USA and China. Under the pressure of the US Steel Casting Union started an anti-dumping investigation on the China imported steel pipes. From 2006 to 2008 the volume of their supplies increased 4 times and reached 2, 6 billion dollars. Under the influence of the steel lobby, the USA introduced the anti-dumping customs duties on the Chinese produce, which suspended new supplies. China immediately responded to this. It considered that the USA abused protectionism. This is only continuation of a whole series of mutual accusations started from September 2009, after the USA introduced 35\% customs duties on the Chinese automobile tyres. Problems in bilateral relations intensified 
in steel casting, paper, automobile, chemical, food industry and they remain up to the present day [Back, 2015].

It is possible that just the unity of such steps, which form barriers on the way of international cooperation, led to a sharp growth of the probability that crisis would go up, which now more often is talked about. According to the WTO statistics, the amount of anti-dumping complaints already in 2009 increased by 16\%, and this took place after reducton of several years and their increase will definitely continue [Haniotis, 2014]. By the calculations of the IFPRI (International Food Product Research Institute), a dangerous growth of tariffs led to $7 \%$ reduction of the international trade [Dadush, 2012].

Thus, we should once more mention that growth of protectionism is an established and sustainable tendency, which dominates in the modern world economy. Introduction of the protectional measures in a short-term perspective will be favorable for some countries and will provoke transition to similar policy of other countries. All this will negatively influence the international trade and will reject the process of liberalization of the national economies. Taking into consideration the above-mentioned arguments that liberalization, as such, is not an absolute and undoubted wellbeing, the recommendations for the government on the need to continue support to progressing changes of used protectionist measures look quite substantiated. It is important to establish an optimal balance between protectionism and economic integration, which is an essential instrument for development of the national economies.

Further integration of Georgia, first of all membership in WTO and liberalization of foreign economic activity (reduction of tariff restructions) requires adequate adaptation of the methods for protection of the home market. As an example, we can consider such strategic and important branch for Georgia as agriculture is. It is also the sphere, in which a wide range of protectionist measures is revealed. The most intensive debates in discussion, concenring further development of the world integration processes, namely, at the Doha round of talks, were dedicated to the protectionist tendencies of agriculture. Talking on agriculture we should outline the system of EU (European Union) measures. United Europe spends about EUR 50 billion a year to support its agriculture [OECED, 2015]. WTO norms are not violated mostly because of well-thought instruments for development of those agrcicultural territories, which are based on the conception of multifunctionality [Krugman, 2006], but on the whole, are oriented on support of the agricultural production. The USA, despite devotion to market economy and free trade, is known for the strong program of support to its agrarian sector. All this witnesses an intensive use of protection mechanisms 
by the developed countries, which do not always support freedom of trade. To study such experience will assist to adapt to the new terms and to raise competitiveness of the Georgian companies within the global competition.

The methods of market support, which are used today in Georgia, often have weak effect. It is necessary to search for new instruments to protect the national producers. In result of study of acting measures for support of the national production, in the near future we'll have to increase the volumes of import established today, after we observe the obligations we shouldered before WTO. At the same time, it should be taken into consideration that any restrictive policy, in the form of direct prohibitions, strict quotas or high tariffs, leads to increase in prices for the inner consumers. In result, this will cause direct reflection of all tariff measures in the final price of commodity. It should be boldly mentioned that numerous attempts of the state to provide more beneficial conditions for the national producers at the expense of classical tariff policy, are compensated by the population of Georgia. Respectively, with introduction of state restrictions on trade, first of all, those buyers are damaged, which are forced to pay for the imported goods, when the producers face risks by losing balance at the home market, as according to the market balance theories they produce goods more than is necessary. In any case, the received balance leads to general losses of economy, at the expense of large losses of the producers, which will outweigh the benefits of the producers and potential income of the state (for example, the budget revenues received from introduction of a tariff, which is its preference over the quotas, but despite this, is not actively used in Georgia). Discussing quotas or subsidies, it should also be mentioned about the expenses of economic subjects on the right to receive financial assistance or quota rent (a permit on selling determined amount of goods at a preferenial price within the quota), which often leads to dishonest competition. Supposing the existence of more efficient trade regimes and optimal compex of measures, which enable maximization of benefit received from foreign economic activity, we consider their introduction in Georgia to be less possible due to serious influence of interested lobbyists. If we discuss the possibility to introduce such assistence to home market of Georgia, we should take into consideration that the interested groups can always be founded, which will manage to advance their interests and to have an impact on adoption of political decisions. Respectively, awareness of the fact, that no ideal political system exists, causes the idea that free trade, as the variant of full absence of regulating measures, will lead to more just and equal terms for all gamblers. 
Despite this, the richest restrictive measures are often used in Georgia. We can remember as an example the restrictions on export of tobacco and alcohol in 2010. Such measures have negative influence on economy. Main declared reason of restrictions - not to permit growth of inner prices - cannot be reached, and the producers, facing such sharp interference, lose any interest in putting long-term investments into the branch. Structutal changes of economy can happen only in result of large-scale changes in economic systems and new orientation of economy. Such changes can be reached at the expense of partial liberalization and intensification of competition. One of the mechanisms of activation of internal resources here is just open economy. For example, free trade, as the result of the process of liberalization, forms preconditions for strengthening and consolidation, which enables to use more efficiently the effect of scale. Along with this, it generates open new competitive environment for innovations and new ideas, allows increase of pressure on the part of foreign organizations and intensifies the need for increase of their competitiveness in modernization. At the same time, the possibilities and need appear to share and study forein experience. But, as we have earlier mentioned, it is necessary to most cautiously use such instruments of development.

The government of Georgia recently conducted gradually the liberalization of the economic activity and consistently expands smooth and controlled economic integration of the country into the world economy. One of the last steps in this direction is removal of customs barriers with Turkey, determined in 2004. Intensification of integration of economy with the European Union (EU) has positive influence and stimulates further development of commodity producers in the country. This effect is also connected with deep relations of both markets and state production sectors. Today it is possible to make prognosis on intensification of integration, increase in goods turnover and freight carryings, and import substitution within the united frames. At the same time, in Georgia, producers in the agricultural sector are forced to reconcile with intensidication of competition and sharp demands of the European market. Despite this, expansion of the production cooperation is expected and further development of other forms of production organization is possible, which will increase competitiveness of the Georgian producers and will compensate an appearance of new demands at the market of Georgia.

Implementation of such projects is an example of institutional changes. Fundamental reforms of market and new rules of game are difficult to be planned, mostly their realization. At the same time, managed liberalization of trade within clearly determined and studied frames will give possibility to prepare ground and to spread further optimization and 
improvement of an institutional base of participant countries. Consideration of the need to remove the tariff restrictions will stimulate development of non-tariff methods of market protection and search for the new balance between the protectionism and deepening of integration.

Such managed integration and cooperation can be given a good stimulus for further development of the national economies of the country. Development of different variants of mutual investments, expansion of industrial and technological cooperation of the companies, coordination of foreign economic policy and protectionist measures acquires new importance for the growth of economies of all the participants. Despite the need for protection of own market, relevantly planned integrational processes represent a powerful instrument for economic development.

\section{Conclusion}

Existence of peculiarities of the large-scale liberalization process and their influence on the national economy and wellbeing of the population is of contradictory character. In conditions, when the interests of the large segments of the population can be damaged, the issues of integration into the world economy pass from the economic to socio-political plane. The present thesis today is clearly seen in the activities of numerous states, which at in conditions of crisis and turbulence, at the markets are in search of variants for protection of the national producers and increase the scales of protectionism. This leads to formation of new institutional terms for functioning of the national economic systems. That's why, gradual integration into the world economy and cautious entrance to the WTO of the countries with the transitional small economy is a substantiated and correct strategy. Stage by stage deepening of the integrational processes and liberalization of trade should be combined with adaptation of the measures of home market assistance, with the formation of new instruments for stimulation of the state protectionism and competitiveness of the national economy.

\section{References}

Back A. (2015) China - U.S. Trade Row Escalates. The Wall Street Journal. 09.11.2015

Bount A. (2016) The Expected Benefits of Trade Liberalization for World Income and Development, Opening the „Black Box“ of Global Trade Modeling. Food Policy Review, 8, IFPRI, Washington.

Charnovitz S. (2016) Resist as Protectionism: The Top Trade Priority for the G20 Rebuilding Global Trade. Collected Articles Jointly Published by International Centre for Sustainable Development. 
Dadush U. (2012) Resurgent Protectionism: Risk and Possible Remedies. Collected Articles Jointly Published by International Centre for Sustainable Development. P.103

Driskill R. (2015) Deconstructing the Argument For Free Trade. Washington. P.132

Haniotis T. (2014) European Commission: DG for Agriculture and Rural Development. Issues of the post 2013 debate. Presentacion. 2 Organic Congress, Brussels. P.311

Krugman P. and Obsveld M. ( 2006) International Economics. Addison-Westley Boston.

Lynn J. (2012) Doha Deal Could Boost World GDP \$ 300-700 billion: Study. Reuters. P.48

OECED (2016) Multifunctionality in Agriculture: Evaluating the Degree Jointness, Policy Implications. P.203

Rodrigues F., Rodric D. (2015) Trade Policy and Economic Growth. University of Maryland. P.54 